\title{
Strategy of Servitization as a Tool for Achievement of Sustainable Development
}

\author{
Vladimira VLCKOVA ${ }^{*}$, David VLCEK ${ }^{1}$ and Lucie KANOVSKÁ ${ }^{2}$ \\ 1 University of Pardubice, Pardubice, Czech Republic; vladimira.vlckova@upce.cz; david.vlcek.upce.cz \\ 2 Brno University of Technology, Brno, Czech Republic; kanovska@fbm.vutbr.cz \\ * Correspondence: vladimira.vlckova@upce.cz
}

\begin{abstract}
The reasons leading companies to the servitization strategy have recently been supplemented with society-wide global trend of striving for sustainable development. To be successful on the current markets, companies invest into services to increase the added value for the customer, diversification, and new income; to ensure the lock-in effect; to use the opportunity to grow and environmental burden reduction. These targets can be achieved by implementation of a strategic approach to servitization. In this paper, a research hypothesis that the manufacturers' strategic approach to servitization has a significant potential to affect achievement of sustainable development in a positive way has been constructed and discussed. The paper outcomes were drawn up based on the analysis, comparison, and synthesis of the information obtained (i) from a targeted professional literature review (ii) from an outcomes of the conducted electronic questionnaire survey. The questionnaire identified the level of the currently provided services related to their products and their expectations concerning an increased interest in services by their management, their customers, and their competitors. The outcomes should then help to direct companies in the Czech Republic to more extensive application of the servitization business model as a strategy supporting sustainable development.
\end{abstract}

Keywords: servitization; services; manufacturing companies; sustainable development

JEL Classification: O14, L10; Q01

\section{Introduction}

In the era of globalization, companies are facing a lot of changes in the market environment. These mainly include the growing competitiveness of developing countries leading, besides other things, to margin compression and market saturation, rapid development of new technologies connected with acceleration of the product innovation cycle, growing demands of the customers and the relating commoditization, shortening of the product life cycle, and changes in the customer demand. At the same time, manufacturing companies face new challenges of a global character with society-wide impacts, particularly on the environment, such as the sharing economy, circular economy, corporate social responsibility, and sustainable development. Elkington (1997) and Maxwell et al. (2006) identified three criteria, namely environment, social and economic, to translate sustainable development into business context. 
To be successful in this highly competitive environment and, at the same time, to satisfy the society-wide demands placed on the business, companies are seeking and considering new business strategies, which would bring a higher customer value, compared to the competitors. One of the options for manufacturers is implementation of the developing business strategies, largely known as servitization. It is the innovation of an organizations capabilities and processes to better create mutual value through a shift from selling product to selling product service system (PSS) (Baines et al., 2009). Since the term servitization was first used by Vandermerwe and Rada (1988), different approaches to services provided by manufacturers have been developed. Differences between them are given partly by the growing demands placed by the customers on the scope and level of the provided services, partly by different motivation and geographical origin of the manufacturers, and partly also by the branch of industry. A successfully implemented PSS should then become a source of income and profits, lead to new opportunities and advantages on the market, to differentiation, and to customer satisfaction. As a result, successful servitization supports not only the manufacturing company itself, but also the entire supply chain or network. Moreover, implementation of a servitization business model itself may also have a significant positive impact on sustainable development. For example, we have recently been coming across the terms of a sustainable service business model (Liu et al., 2014), sustainable PSS (Vezzoli et al., 2015), IPSS (The integrated product service system) which is in compliance with conforming to triple bottom lines of sustainability, and Scandinavian concept PSS which is closely coupled to the debates on sustainability and the reduction of environmental impact (Baines et al., 2009).

However, the outcomes of the website analyses and structured interviews conducted with selected chemical companies in the Czech Republic in 2018 and 2019 imply that although the companies provided a wide portfolio of services, these were mostly rather complementary services connected with a product in an effort to extend their portfolio to increase the product sales. The manufacturing companies only sporadically offered advanced services closely related to a product in cooperation with other supply-chain entities (Vlckova \& Podskubkova, 2020). Manufacturing companies in the Czech Republic use servitization as a tool fulfilling their marketing targets, rather than as a way of redirecting their strategic orientation towards PSS. In fact, the main target of the marketing approach to servitization is differentiation of the offer to the customers, where products and services can be separated and sold separately (Pistoni \& Songini, 2018). On the other hand, the modern strategic approach represents innovation of corporate abilities and processes to achieve a shift from the sale of products (product-dominant logic) to the sale of a product-service system (servicedominant logic), which better creates both the customer and the supplier value (Kryvinská et al., 2014). The manufacturer's and the customer's sources are being integrated and information is being shared mutually to make it possible for the manufacturer to help the customer reach their targets, which should, on top of that, also respect the society-wide requirement concerning permanently sustainable development. This requirement is also a part of the strategic document ČR 2030. It specifies the direction of our country in the next decade. It defines long-term priorities of the development of the Czech Republic, whose 
fulfilment will help to increase the quality of life in all the regions and will direct the Czech Republic to development that is sustainable in social, economic, and environmental aspects. (Úřad vlády ČR, 2017)

Therefore, we formulated a research hypothesis: the manufacturers' strategic approach to servitization has a significant potential to affect achievement of sustainable development in a positive way. To verify this hypothesis, we set the following targets: to conduct a targeted professional literature review, focusing on the manufacturers' strategic approach to servitization, particularly on the reasons and circumstances leading the companies to this business model. Then, to conduct a survey among companies in the Czech Republic, which should bring more detailed information about the provided services from the point of view of their scope and relation to the offered products. Then, based on these outcomes, to identify the influence and possibilities of servitization with respect to achievement of sustainable development. The outcomes should then help to direct companies in the Czech Republic to more extensive application of the servitization business model as a strategy supporting sustainable development.

\section{Methodology}

The formulated hypothesis was verified using primary and secondary sources. The used secondary sources mainly included foreign professional articles, professional studies, and company websites.

The primary sources refer to the outcomes of the electronic questionnaire survey we conducted with the companies belonging, based on their main business activity, to Sections 20 (Manufacture of chemicals and chemical products), 24 (Manufacture of basic metals), 26 (Manufacture of computer, electronic and optical products) and 27 (Manufacture of electrical equipment) under the CZ-NACE classification of economic activities.

The companies were addressed in September 2020 through their email addresses acquired from the Amadeus database (database of comparable financial information for public and private companies across Europe), where they were sent a link to an online questionnaire created in the tool Lime Survey. In total questionnaires were sent 820 companies. The questionnaire contained 23 questions, structured in accordance with the branch of industry where they classified themselves. The questionnaire identified the level of the currently provided services related to their products and their expectations concerning an increased interest in services by their management, their customers, and their competitors. The paper outcomes were processed based on the analysis, comparison, and synthesis of the obtained information.

\section{Results}

\subsection{The Reasons for Servitization}

The reasons leading industrial companies to introduction of the concept of servitization can be different. They mainly include commoditization, market saturation (Pistoni \& Songini, 2018; Vandermerwe \& Rada, 1988), acceleration of the product innovation cycle (Benedettini 
et al., 2015), competitive pressure, globalization, new technologies (Vandermars \& Rada, 1988), and recently also environmental circumstances (Ahamed et al., 2013) pushing the society-wide global trend towards sustainable development.

The company's external environment and internal conditions, and thus also different reasons for servitization, are affected by the branch of business the company belongs to (Turunen \& Finne, 2014)). Kryvinská et al. (2014) divides these reasons into three groups, i.e. general trends in management (external reasons), financial factors and strategic reasons (internal reasons). General trends leading companies to introduction of servitization include: a companies' shift from product orientation to solution orientation, which should complete them; shift from outputs to outcomes, transactions to relationships (e.g. making contracts with customers, guaranteeing a volume of sales); shift from suppliers to network partners; a shift from orientation to separate elements to complex ecosystems.(Neely et al., 2011)

The internal reasons for servitization relate to managerial decision-making (Pistoni \& Songini, 2018). The financial reasons relate to the customers' pressure on the profit margins, which results in the suppliers' problems with achievement of higher income through the sale of products, particularly commodities. Therefore, they are starting to invest into services as a source of diversification (Pistoni \& Songini, 2018) and new income (Ahamed et al., 2013). Moreover, a significant effect is origination of a so-called lock-in effect, as it is the manufacturer who can develop, sell, and deliver services best of all. The strategic reasons then relate to the suppliers' efforts to acquire competitive advantage (Ahamed et al., 2013) by providing a range of services that is as specific and intensive as possible (Kryvinská et al., 2014).

Therefore, companies can see servitization as an opportunity: how to differentiate themselves from competitive offers through extension of their own offerings by services and to increase the product sales and customer loyalty this way (Pistoni \& Songini, 2018); how to compete with mass production of large companies without a significant long-term increase in the costs (Neely, 2008); how to get more opportunities for growth as the area of services is more profitable than the area of products (Ahamed et al., 2013; Pistoni \& Songini, 2018). However, it is necessary to note that introduction of servitization is not necessarily always of benefit to the company, e.g. in the case of a high role and function of products in operations, or in an unstable operational product environment at the customers' premises (e.g. it did not prove successful in the case of construction machines used outside companies). Then we speak about undervalued services, which do not bring an increased customer value (Jovanovic et al., 2016).

\subsection{The Integration of Products and Services - Opportunity for Sustainable Development}

Servitization obviously includes both innovation of offerings, and innovation of the manufacturing process and operation. Servitization can be represented by three steps, characterized by different levels of offering complexity and by integration of different products and services, which naturally affects the entire process of satisfying customer requirements. In the first step of servitization, a product offering is supported by a few 
product services focused on improvements of its functionality; in the second step, some product services aiming to improve the processes and some customer services improving the relationships with customers are added. In the last step, products and services combine into a new and unique offering in the form of a product-service system - PSS (Pistoni \& Songini, 2018).

Integration of products and services itself can then take place in various ways. Park et al. (2012) divides them into two groups. The first group is based on the marketing approach, and it contains different forms of integration of product services aiming to observe the marketing targets, i.e. differentiation of the company's offering and increasing sales. However, there is a relatively small space left for further improvements in the Environment and ecology, which is more or less on the part of the manufacturer. It can refer e.g. to improvements in a technological process, modernization of technologies, etc. However, this usually requires considerable investments. In the period of the pressure on price reduction resulting from severe competition, companies usually stay in this area on the level of the parameters of their products, technologies, etc., given by the statutory limits. Only few customers are, for the time being, willing to pay more for a more environmentally friendly product.

The second group of the ways of integration is then based on the strategic approach, and it refers to a change in the corporate strategic orientation. Most of these approaches to product-service integration did not develop until after 2000, and they include Solutions (Miller et al., 2002), Integrated solutions, Product-service system (Manzini \& Vezzoli, 2003), Functional sales (Aurich et al., 2006), Function product (Alonso-Rasgado et al., 2004), Integrated product and service engineering (Pistoni \& Songini, 2018).

However, to verify our hypothesis, the last three ways are most important. Functional sales represent a comprehensive solution consisting of a combination of products and services satisfying the identified customer need, taking account of the entire product or service lifetime, from its design to manufacturing. (Aurich et al., 2006). In the case of integration into a function product, the customer purchases a function provided by a function product, e.g. space cleaning instead of a cleaning detergent (Alonso-Rasgado et al., 2004). The highest form of servitization is then Integrated product and service engineering. This concept incorporates the properties of a function product in the way to aim at the functions delivered to the customer and at the complete integration of various components into corporate offerings to better satisfy the customer needs (Pistoni \& Songini, 2018). All these three ways of integration of servitization create huge opportunities just for sustainable development. As an example from personal practice, we can mention a company manufacturing, and earlier only selling, catalysts, which has agreed with one of their customers on delivery of solutions in the form of ensuring proper functioning of the catalyst. It means that the catalyst manufacturer monitors the effectiveness of the catalyst in the customer's operations and ensures its partial regeneration and replacement. Differently from the previous way, where the catalyst was only replaced and disposed, but not regenerated. As the customer pays for the function, but not for the quantity of the catalyst and the supplier is a catalyst expert, this results not only in a significant decrease in the consumption of the catalyst and all the sources 
necessary for its replacement and disposal, but also in an increase in its effectiveness in the customer. This leads both to a decrease in the cost of the catalyst, and mainly to further reduction of the environmental burden. Another example can be reduction of carbon footprint using advanced services to monitor machine performance.

However, implementation of the strategic approach to servitization is much more demanding than in the case of the marketing approach. It is related to creation of a new form of corporate organization, its integration/change in the position in the supply chain, a change in its structure, culture, and management control systems. It requires investments, a change in the corporate attitude, and strong confidence.

Servitization mainly refers to services provided on the B2B market, where they are offered together with a product for the purpose of increasing its added value. They are often divided into services supporting a product (e.g. warehousing, transport, installation, training of workers, maintenance, and guarantee period services) and 'pure' services (e.g. marketing surveys, financial services, consultancy in the areas of management, finance, and law) (Ellis, 2011). They can also be divided in accordance with their relation to the product itself and the possibility of their growth on the industrial market (Raddats \& Easingwood, 2010).

Our questionnaire was based on classification of services according to their orientation to outcome, i.e.: basic services (their outcome is focused on provision of products, facilities, ensuring spare parts, guarantee, etc.), intermediation services (they are focused on maintaining the product condition, e.g. status monitoring, on-site services, scheduled maintenance, technical assistance services, repairs, direct-to-site delivery, installation, training of operators), and advanced services (whose outcome is oriented to the abilities delivered together through the product performance, e.g. takeover of product performance control by the service provider, contractual provision of customer support and related contract on risks a reward sharing, revenue-through-use contract and rental agreement). (Baines \& Lightfoot, 2013,) We added category Smart services (they use new smart technologies to collect data from the operation of a facility or equipment at the customer site and to analyze them). These services then aim to increase productivity decrease the failure rate, increase the operating cost efficiency and the operations safety (Kaňovská, 2018). As a result, they can significantly contribute to sustainable development, e.g. through the above carbon footprint reduction.

\subsection{Services Provided by Manufacturing Companies in the Czech Republic (Survey Outcomes)}

Individual types of services obviously differ in accordance with the branch of business the service provider operates in, and in accordance with their prevailing customers from the point of view of their share in profit creation, i.e. according to the fact, whether the customers are manufacturer (B2B), end consumers (B2C), or intermediaries (distributors). Therefore, we chose two groups of industries for our research.

- Group CZ-NACE 20 (Manufacture of chemicals and chemical products) and 24 (Manufacture of basic metals), 
- Group CZ-NACE 26 (Manufacture of computer, electronic and optical products) and 27 (Manufacture of electrical equipment).

The rule was that members of one group operate in very similar branches of business, while the groups differ from each other significantly in terms of their products, type of production, applied technologies, and so also in terms of the possibilities of services suitable for servitization. On the other hand, we dare to declare that we know these branches of business from our previous scientific activity at the given faculties.

That is why the questionnaire was structured in the way to first divide the respondents into the above groups by industry. Assignment of questions to individual groups relating to the respective types of services is specified in Table 1.

Table 1. Questions on individual types of services provided

\begin{tabular}{|c|c|c|}
\hline \multirow{2}{*}{$\begin{array}{c}\text { Questions: Do you } \\
\text { provide your customers } \\
\text { with: }\end{array}$} & \multicolumn{2}{|c|}{ Examples of provided services } \\
\hline & 1st Group & 2nd Group \\
\hline $\begin{array}{c}\text { Basic accompanying } \\
\text { services }\end{array}$ & $\begin{array}{l}\text { - necessary product information (incl. } \\
\text { necessary documentation, samples; tests, etc.); } \\
\text { - professional consultancy for the serviced } \\
\text { type of customer to the technology and } \\
\text { product usage, } \\
\text { - training, helpdesk }\end{array}$ & $\begin{array}{l}\text { - necessary product } \\
\text { information (incl. necessary } \\
\text { documentation, } \\
\text { - services related to product } \\
\text { delivery and invoicing }\end{array}$ \\
\hline $\begin{array}{c}\text { Advanced accompanying } \\
\text { services }\end{array}$ & $\begin{array}{c}\text { - environmental programs: } \\
\text { - assistance with waste reduction, recycling, } \\
\text { and waste disposal, } \\
\text { - logistic services: supplying, warehousing, } \\
\text { transport, professional consultancy for } \\
\text { finetuning processes; -process optimization; } \\
\text { - safety programs; } \\
\text { - product quality control }\end{array}$ & $\begin{array}{l}\text { - ensuring spare parts, } \\
\text { service/inspections, first } \\
\text { training, } \\
\text { preventive service } \\
\text { maintenance, } \\
\text { service-level agreements }\end{array}$ \\
\hline $\begin{array}{l}\text { Complete and } \\
\text { comprehensive solutions, } \\
\text { i.e. products in the form of } \\
\text { services (complex services) }\end{array}$ & $\begin{array}{l}\text { - protection, cleaning, or disinfection of } \\
\text { materials, equipment, production halls at the } \\
\text { customer site; } \\
\text { - pest control, } \\
\text { - coating, painting, another treatment of } \\
\text { facilities/ materials; } \\
\text { - ensuring operation and service on the } \\
\text { equipment at the customer site (effectiveness } \\
\text { monitoring, catalyst regeneration and } \\
\text { replacement, oil lubrication, including regular } \\
\text { inspections), } \\
\text {-provision of tests, service, and guarantees for } \\
\text { overall flawless operation of the equipment }\end{array}$ & $\begin{array}{l}\text { - product design, where the } \\
\text { end customer does not have } \\
\text { to solve technical details of } \\
\text { the product, and the supplier } \\
\text { is the one who solely ensures } \\
\text { the entire product operation } \\
\text { and service, including } \\
\text { regular inspections, } \\
\text { service, repairs, and } \\
\text { guarantees overall flawless } \\
\text { operation of the product }\end{array}$ \\
\hline $\begin{array}{l}\text { Accompanying services } \\
\text { using smart technologies, } \\
\text { so called smart services }\end{array}$ & $\begin{array}{c}\text { - remote monitoring, } \\
\text { - remote diagnostics, } \\
\text { - remote repairs, } \\
\text { - predictive maintenance, etc. }\end{array}$ & $\begin{array}{l}\text { - remote monitoring, } \\
\text { - remote diagnostics, } \\
\text { - remote repairs, } \\
\text { - predictive maintenance, etc. }\end{array}$ \\
\hline
\end{tabular}

The questionnaire was filled in by 88 companies in total, 33 of them in Group 1 and 55 in Group 2. Most of them supplied B2B market, and most companies had up to 50 employees. If we are to suppose that the questionnaire was mainly filled in by companies interested in 
servitization, this result was expected in view of the facts that small companies are usually more flexible and that the questions were mainly aimed at services complementing a product.

For the outcomes of the questioning conducted with the companies concerning the respective types of provided services structured by group of branches of business, prevailing customers and company size, see Tables 2 and 3.

Table 2. The proportions of companies from Group 1 divided according types of provided services as structured by prevailing customers and company size

\begin{tabular}{|c|c|c|c|c|c|c|}
\hline \multirow{2}{*}{ Type of provided services } & $\begin{array}{c}\text { Number of } \\
\text { companies }\end{array}$ & Basic & Advanced & Complex & Smart \\
\hline \multirow{2}{*}{$\begin{array}{c}\text { Prevailing } \\
\text { customers }\end{array}$} & B2B & 21 & $100 \%$ & $71 \%$ & $24 \%$ & $5 \%$ \\
\cline { 2 - 7 } & B2C & 5 & $100 \%$ & $60 \%$ & $20 \%$ & $20 \%$ \\
\cline { 2 - 7 } & Intermediaries & 7 & $100 \%$ & $43 \%$ & $29 \%$ & $0 \%$ \\
\hline \multirow{2}{*}{\begin{tabular}{c} 
The size of \\
the company \\
according to \\
the number \\
\cline { 2 - 7 } of employees
\end{tabular}} & Notal Answered & 73 & $100 \%$ & $64 \%$ & $24 \%$ & $6 \%$ \\
\cline { 2 - 7 } & Small (do 50) & 12 & $100 \%$ & $67 \%$ & $17 \%$ & $8 \%$ \\
\cline { 2 - 7 } & Large (250 and more) & 4 & $100 \%$ & $100 \%$ & $50 \%$ & $25 \%$ \\
\cline { 2 - 7 } & Total & 33 & $100 \%$ & $64 \%$ & $24 \%$ & $6 \%$ \\
\hline
\end{tabular}

All 33 companies from Group 1 who filled in the questionnaire completely provide basis services regardless of the customer type or their size see Table 2. Together with the growing complexity of the provided services, the number of companies providing them gradually significantly decreases. Intermediaries and medium-sized companies don't even provide any smart services. The other companies do, but sporadically only. From two to three times more companies (ca. 70\% small and medium companies, and at B2B) then declared provision of an advanced service than it was with provision of a comprehensive solution for customers (between $20 \%$ and $30 \%$ companies).

Table 3. The proportions of companies from Group 2 divided according types of provided services as structured by prevailing customers and company size.

\begin{tabular}{|c|c|c|c|c|c|c|}
\hline \multirow{4}{*}{ Type of provided services } & $\begin{array}{r}\text { Number of } \\
\text { companies }\end{array}$ & Basic & Advanced & Complex & Smart \\
\hline \multirow{2}{*}{$\begin{array}{c}\text { Prevailing } \\
\text { customers }\end{array}$} & B2B & 30 & $87 \%$ & $70 \%$ & $33 \%$ & $33 \%$ \\
\cline { 2 - 7 } & B2C & 12 & $100 \%$ & $83 \%$ & $50 \%$ & $42 \%$ \\
\cline { 2 - 7 } & Intermediaries & 13 & $100 \%$ & $92 \%$ & $31 \%$ & $54 \%$ \\
\cline { 2 - 7 } & Total & 55 & $93 \%$ & $78 \%$ & $36 \%$ & $40 \%$ \\
\hline \multirow{2}{*}{$\begin{array}{c}\text { The size of } \\
\text { the company } \\
\text { according to } \\
\text { the number of } \\
\text { employees }\end{array}$} & Not Answered & 11 & $91 \%$ & $82 \%$ & $36 \%$ & $36 \%$ \\
\cline { 2 - 7 } & Ledium (51 - 250) & 12 & $83 \%$ & $50 \%$ & $17 \%$ & $42 \%$ \\
\cline { 2 - 7 } & Large (250 and more) & 10 & $100 \%$ & $100 \%$ & $60 \%$ & $60 \%$ \\
\cline { 2 - 7 } & Total & 55 & $93 \%$ & $78 \%$ & $36 \%$ & $40 \%$ \\
\hline
\end{tabular}


Almost $100 \%$ of the companies from Group 2, see Table 3, also provide basic services. Similarly, growing (with exception of smart services) complexity of services results in a decreasing number of their providers, as it is among Group 1 companies. However, the decrease is not as dramatic, and, except for medium-sized companies, more than $70 \%$ of the companies provide advanced services, and more than one third of them provide comprehensive services. As for large companies and B2C offerings, it is even more than $50 \%$ companies. The biggest difference in the expectations between the selected groups is in smart services. While in the first group, there were in total $6 \%$ of providers of these services, in the second group there were $40 \%$ of them.

\subsection{Expectations Concerning Increased Interests of Services Provided by Manufacturing Companies in the Czech Republic (Survey Outcomes)}

The questionnaire also asked whether the manufacturing companies expect an increased interest of their customers, their management, and their competitors in individual types of services. The questions relating to their expectations concerning customers were answered by 77 companies, concerning management by 74 companies, and concerning competitors by 70 companies. Result are shown in Tables 4 and 5.

Table 4. The proportions of companies divided according to their expectations concerning increased interests on the part of their selected stakeholders in types of services

\begin{tabular}{|c|c|c|c|c|c|c|c|c|c|c|c|c|c|}
\hline \multicolumn{2}{|c|}{ Type of service } & \multicolumn{3}{|c|}{ Basic } & \multicolumn{3}{|c|}{ Advanced } & \multicolumn{3}{|c|}{ Complex } & \multicolumn{3}{|c|}{ Smart } \\
\hline $\begin{array}{c}\text { Expectations } \\
\text { of: }\end{array}$ & $\begin{array}{c}\text { No. of } \\
\text { Co. }\end{array}$ & Yes & $\begin{array}{l}\text { Don't } \\
\text { know }\end{array}$ & No & Yes & $\begin{array}{l}\text { Don't } \\
\text { know }\end{array}$ & No & Yes & $\begin{array}{l}\text { Don't } \\
\text { know }\end{array}$ & No & Yes & $\begin{array}{l}\text { Don't } \\
\text { know }\end{array}$ & No \\
\hline Customers & 77 & $32 \%$ & $26 \%$ & $42 \%$ & $29 \%$ & $29 \%$ & $43 \%$ & $31 \%$ & $29 \%$ & $40 \%$ & $31 \%$ & $32 \%$ & $36 \%$ \\
\hline Management & 74 & $42 \%$ & $19 \%$ & $39 \%$ & $30 \%$ & $26 \%$ & $45 \%$ & $35 \%$ & $20 \%$ & $45 \%$ & $39 \%$ & $27 \%$ & $34 \%$ \\
\hline Competitors & 70 & $39 \%$ & $27 \%$ & $34 \%$ & $34 \%$ & $30 \%$ & $36 \%$ & $34 \%$ & $33 \%$ & $33 \%$ & $31 \%$ & $36 \%$ & $33 \%$ \\
\hline
\end{tabular}

Table 5. The proportions of companies divided according to their expectations concerning increased interests on the part of their selected stakeholders in types of services as structured by industry.

\begin{tabular}{|c|c|c|c|c|c|c|c|c|c|c|c|c|c|c|}
\hline \multirow[b]{2}{*}{$\begin{array}{c}\text { CZ- } \\
\text { NACE }\end{array}$} & \multicolumn{2}{|c|}{ Type of service } & \multicolumn{3}{|c|}{ Basic } & \multicolumn{3}{|c|}{ Advanced } & \multicolumn{3}{|c|}{ Complex } & \multicolumn{3}{|c|}{ Smart } \\
\hline & $\begin{array}{c}\text { Expectations } \\
\text { of: }\end{array}$ & $\begin{array}{c}\text { No. of } \\
\text { Co. }\end{array}$ & Yes & $\begin{array}{l}\text { Don't } \\
\text { know } \\
\end{array}$ & No & Yes & $\begin{array}{l}\text { Don't } \\
\text { know }\end{array}$ & No & Yes & $\begin{array}{l}\text { Don't } \\
\text { know }\end{array}$ & No & Yes & $\begin{array}{l}\text { Don't } \\
\text { know }\end{array}$ & No \\
\hline \multirow{3}{*}{$\begin{array}{c}20 \& \\
24 \\
\end{array}$} & Customers & 28 & $46 \%$ & $29 \%$ & $25 \%$ & $39 \%$ & $32 \%$ & $29 \%$ & $43 \%$ & $29 \%$ & $29 \%$ & $29 \%$ & $46 \%$ & $25 \%$ \\
\hline & Management & 26 & $62 \%$ & $15 \%$ & $23 \%$ & $42 \%$ & $27 \%$ & $31 \%$ & $42 \%$ & $19 \%$ & $38 \%$ & $38 \%$ & $35 \%$ & $27 \%$ \\
\hline & Competitors & 26 & $58 \%$ & $27 \%$ & $15 \%$ & $42 \%$ & $31 \%$ & $27 \%$ & $42 \%$ & $31 \%$ & $27 \%$ & $31 \%$ & $38 \%$ & $31 \%$ \\
\hline \multirow{3}{*}{$\begin{array}{c}26 \& \\
27\end{array}$} & Customers & 49 & $24 \%$ & $24 \%$ & $51 \%$ & $22 \%$ & $27 \%$ & $51 \%$ & $33 \%$ & $29 \%$ & $39 \%$ & $33 \%$ & $24 \%$ & $43 \%$ \\
\hline & Management & 48 & $31 \%$ & $21 \%$ & $48 \%$ & $23 \%$ & $25 \%$ & $52 \%$ & $31 \%$ & $21 \%$ & $48 \%$ & $40 \%$ & $23 \%$ & $38 \%$ \\
\hline & Competitors & 44 & $27 \%$ & $27 \%$ & $45 \%$ & $30 \%$ & $30 \%$ & $41 \%$ & $30 \%$ & $34 \%$ & $36 \%$ & $32 \%$ & $34 \%$ & $34 \%$ \\
\hline
\end{tabular}

Table 4 outcomes show that about one third of companies expect an increased interest in each type of service from their customers, and a little more from their management. 19-33\% of the companies do not know what they can expect from in the area of development of services from their customers, their management, or their competitors. As many as $45 \%$ of the companies do not expect any growing interest in certain services. If we look at these 
outcomes more closely, see Table 5, we can see that the expectations of companies from different branches of business differ.

As for industries in Group 1, see Table 5, higher or the same percentage of companies always expect a growing interest in a type of services (29-62\%), compared to the companies expecting no increase in the given service (15-38\%). As for Group 2, with one exception (management's interest in smart services), it is in the opposite way. The percentage of companies expecting no increase in the interest in a type of service is always higher (34-52\%), than that of companies expecting a growing interest in the given service (22-33\%). The biggest difference in the expectations among the chosen groups is in basic services, where more than $46 \%$ of Group 1 companies expect a growing interest in these services on the part of their management, their competitors, and their customers. On the other hand, less than $31 \%$ of Group 2 companies expect a growing interest in basic services. The smallest differences are in the expectations of a growing interest in smart services.

\section{Discussion and Conclusions}

The reasons leading industrial companies to the servitization strategy have recently been supplemented with society-wide global trends: solving environmental issues, worsening environment, and striving for sustainable development. The reasons for which companies approach different forms of product-service integration (servitization) are affected by the company's external environment and the internal conditions that are also related to the industry the company belongs to. To be successful on the current markets, companies invest into services to increase the added value for the customer, diversification, and new income; to ensure the lock-in effect; to use the opportunity to grow and environmental burden reduction. The above targets can be achieved through services by implementation of a strategic approach to servitization. That means mainly by implementation of comprehensive solutions (complex services) and smart services. However, implementation of servitization does not necessarily always have to be of benefit. It is necessary to keep an eye on services undervalued by the customers.

The questioning outcomes imply that practically all of 88 companies filling in the questionnaire provide basic services, regardless of the branch of their business. For companies from CZ-NACE 20 and 24 (see Table 2) is fact that the number of companies providing services is gradually significantly decreasing together with growing complexity of these services. Advanced services are provided by $64 \%$ of the companies, complex services by $24 \%$ of the companies, and smart services by a negligible number only (6\%).

As for Group 2 companies (see Table 3) there we can also see the trend of a decreasing number of providers together growing complexity of provided services (except smart services), but the decline is not so sharp. Advanced services are provided by $78 \%$ of the companies, complex services by $36 \%$ of the companies. For large companies and offers on $\mathrm{B} 2 \mathrm{C}$, it is even over $50 \%$ of companies. However, the biggest difference between the groups is in provision of smart services, which are provided by significantly more companies from Group 2, i.e. $40 \%$. This difference is, in view of the close relations among the branches of 
business of production of computers, electronic and optical apparatuses and devices, and production of electrical facilities and the contents of smart services (see Table 1) is explicable.

If we come out of the fact that they are just advanced services, and particularly entire comprehensive solutions and smart services being applied in the strategic approach to servitization (see the research outcomes) can most contribute to sustainable development, then it is possible, in view of still unused potential of these services, particularly in Group 1 companies, to make a conclusion about acceptance of the formulated hypothesis, i.e. that a strategic approach of manufacturing companies to servitization has a significant potential to affect achievement of sustainable development in a positive way.

As for the other research outcomes, see Table 4, it is possible to see a positive fact that, in each type of service, almost one third of the companies expect an increased interest on the part of their customers, and also the fact that a similar number of companies expect an increased interest in these services on the part of their management. What is a little surprising, in view of the growing trend of transition to servitization, is the finding that as many as $45 \%$ of the companies do not expect a growing interest in certain services, and 19$33 \%$ of the companies do not even know what they can expect in the area of service development from their customers, their management, or their competitors. These companies probably still have not duly appreciated the importance of servitization.

A more detailed analysis (see Table 5) affirmed our assumption that expectations of companies differ in different branches of business. As for Group 1 companies, a higher or the same percentage of companies always expect an increased interest in a type of service, compared to the number of companies expecting no increase in the interest in the given service. As for Group 2, except for management expectations concerning a smart service, it is in the opposite way. It can also be given by the fact that more Group 2 companies are already using higher forms of servitization (see Table 2). The biggest difference in the expectations between the selected groups is in basic services. A growing interest in these services is expected by more companies in Group 1 . The reason can be found in the fact that companies belonging to NACE 20 and 24 still perceive implementation of services rather on the level of the marketing approach to servitization aiming to increase the sales of their products, but also higher demands concerning implementation of the strategic approach to servitization. However, it is possible to expect, taking account of the society-wide global trend to sustainable development, that these companies will gradually seek, under the pressure of the competition and customers, ways where and how to implement the strategic approach to servitization.

Acknowledgments: This study was supported by a grant from the Fund for Bilateral Relations within the framework of the EEA and Norway Grants 2014-2021 (EHP-BFNU-OVNKM-3-134-01-2020).

\section{References}

Ahamed, Z., Kamoshida, A., \& Inohara, T. (2013). Organizational Factors to the Effectiveness of Implementing Servitization Strategy. Journal of Service Science and Management, 6, 177-185, https://doi.org/10.4236/jssm.2013.62018

Alonso-Rasgado, T., Thompson, G., \& Elfström, B. O. (2004). The design of functional (total care) products. Journal of Engineering Design, 15(6), 515-540. https://doi.org/10.1080/09544820412331271176 
Aurich, J. C., Fuchs, C., \& Wagenknecht, C. (2006). Life cycle-oriented design of technical Product-Service Systems. Journal of Cleaner Production, 14(17), 1480-1494. https://doi.org/10.1016/j.jclepro.2006.01.019

Baines, T., \& Lightfoot, H. (2013). Made to serve: how manufacturers can compete through servitization and product service systems. John Wiley \& Sons.

Baines, T. S., Lightfoot, H. W., Benedettini, O., \& Kay, J. M. (2009). The servitization of manufacturing: A review of literature and reflection on future challenges, Journal of Manufacturing Technology Management, 20(5), 547-567. https://doi.org/10.1108/17410380910960984

Benedettini, O., Neely, A., \& Swink, M. (2015). Why do servitized firms fail? A risk-based explanation. International Journal of Operations \& Production Management, 35(6), 946-979. https://doi.org/10.1108/IJOPM02-2014-0052

Elkington, J. (1997). Cannibals with Forks, The Triple Bottom Line of 21st Century Business. Calstone Publishing Limited. Ellis, N. (2011). Business-to-business marketing: relationships, networks and strategies (2nd ed.). Oxford University Press. Jovanovic, M., Engwall, M., \& Jerbrant, A. (2016). Matching Service Offerings and Product Operations: A Key to Servitization Success. Research Technology Management, 59(3), 29-36. https://doi.org/10.1080/08956308.2016.1161403

Kaňovská, L. (2018). Využití smart technologii ve službách průmyslových podniků. Akademické nakladatelství CERM.

Kryvinská, N., Kaczor, S., Strauss, C., \& Greguš, M. (2014). Servitization Strategies and Product-Service-Systems, 2014 IEEE World Congress on Services (pp. 254-260). IEEE. https://doi.org/10.1109/SERVICES.2014.52.

Liu, C. H., Chen, M.-C., Tu, Y.-H., \& Wang, C.-C. (2014). Constructing a sustainable service business model: An S-D logic-based integrated product service system (IPSS). International Journal of Physical Distribution $\mathcal{E}$ Logistics Management, 44(1-2), 80-97. https://doi.org/10.1108/IJPDLM-02-2013-0039

Manzini, E., \& Vezzoli, C. (2003). A strategic design approach to develop sustainable product service systems: Examples taken from the 'environmentally friendly innovation' Italian prize. Journal of cleaner production, 11(8), 851-857. https://doi.org/10.1016/S0959-6526(02)00153-1

Maxwell, D., Sheate, W., \& van der Vorst, R. (2006). Functional and systems aspects of the sustainable product and service development approach for industry. Journal of Cleaner Production, 14(17), 1466-1479. https://doi.org/10.1016/j.jclepro.2006.01.028

Miller, D., Hope, Q., Eisenstat, R., Foote, N., \& Galbraith, J. (2002). The problem of solutions: Balancing clients and capabilities. Business Horizons, 45(2), 3-12. https://doi.org/10.1016/S0007-6813(02)00181-7

Neely, A. (2008). Exploring the financial consequences of the servitization of manufacturing. Operations Management Research, 1, 103-118. https://doi.org/10.1007/s12063-009-0015-5

Neely, A., Benedetinni, O., \& Visnjic, I. (2011). The Servitization of Manufacturing - Further Evidence. In Proc. 18th European Operations Management Association Conference. University of Cambridge. https://www.researchgate.net/publication/265006912_The_Servitization_of_Manufacturin g_Further_Evidence

Park, Y., Geum, Y., \& Lee, H. (2012). Toward integration of products and services: Taxonomy and typology. Journal of Engineering and Technology Management 29(4), 528-545. https://doi.org/10.1016/j.jengtecman.2012.08.002

Pistoni, A., \& Songini, L. (2018). Servitization strategy and managerial control. Emerald Publishing.

Raddats, C., \& Easingwood, C. (2010). Services growth options for B2B product-centric businesses. Industrial Marketing Management 39(8), 1334-1345. https://doi.org/10.1016/j.indmarman.2010.03.002

Turunen, T., \& Finne, M., (2014). The organisational environment's impact on the servitization of manufacturers. European Management Journal, 32(4), 603-615. https://doi.org/10.1016/j.emj.2013.11.002

Úřad vlády ČR. (2017). Strategický rámec Česká republika 2030. https://www.cr2030.cz/strategie/dokumenty-kestazeni/

Vandermerwe, S., \& Rada, J. (1988). Servitization of business: adding value by adding services. European Management Journal, 6(4), 314-324. https://doi.org/10.1016/0263-2373(88)90033-3

Vezzoli, C., Ceschin, F., Diehl, J. C., \& Kohtala, C. (2015). New Design Challenges to Widely Implement 'Sustainable Product-Service Systems'. Journal of Cleaner Production, 97, 1-12. https://doi.org/10.1016/j.jclepro.2015.02.061

Vlckova, V., \& Podskubkova, L. (2020). The Approach to Servitization in the Czech Manufacturing Companies. In P. Jedlička, P. Marešová, K. Firlej, \& I. Soukal (Eds.), Proceedings of the international scientific conference Hradec Economic Days 2020 (pp. 861-870). University of Hradec Králové. https://doi.org/10.36689/uhk/hed/2020-01-097 